\title{
DEVELOPMENT OF "GAMES 3 ON 3" LEARNING TECHNIQUES IN VOLLEYBALL
}

\author{
Destriani $^{1}$, Herri Yusfi ${ }^{2}$, Destriana ${ }^{3}$, Silvi Aryanti ${ }^{4}$ \\ Universitas Sriwijaya ${ }^{1,2,3,4}$ \\ destriani@fkip.unsri.ac.id ${ }^{1}$, herriyusfi@fkip.unsri.ac.id ${ }^{2}$, \\ destriana@fkip.unsri.ac.id ${ }^{3}$, silviaryanti@fkip.unsri.ac.id ${ }^{4}$
}

\begin{abstract}
The development of varied learning techniques can help educators to design learning creatively so that the learning process becomes innovative, interesting, more qualified and can improve student learning outcomes, in connection with existing game designs, providing students with opportunities to develop skills, knowledge, and rules that related to the structure of the game that leads to discovery and imagination for students. So as educators, there are many methods and strategies that can be used in the learning process. Every educator is given the opportunity to facilitate the learner's learning experience by using a student-centred approach. This study aims to develop a "games 3 on 3" learning technique in volleyball games for students of Physical Education, Health, and Recreation, Faculty of Teacher Training and Education, Sriwijaya University. The research method used is research and development. The development research used is the Borg and Gall model. The stages of activities in this research are needs analysis, planning, development of initial product drafts, initial field trials, revision of test results, small-scale product field tests, product revisions, large-scale field trials or feasibility tests, and final product revisions. In the expert validation stage, there are two validators, namely volleyball game experts and physical education learning, this stage obtained an average value of $68.9 \%$ in the cognitive domain, $70 \%$ in the psychomotor domain and $72.9 \%$ in the affective domain and entered in the category is sufficient and can be continued in field trials by improving learning products in accordance with suggestions and input from the validator. The results at the field trial stage in 3 cognitive, psychomotor, and affective domains with values of $83.03 \%, 81.25 \%$, and $77.08 \%$, it can be concluded that the development of "3 on 3 games" is effectively used for learning volleyball games, with development results in the form of changes in the size of the field, the rules of the game, and the final score in each set. "Games 3 on 3" in volleyball games can be used for learning volleyball games and can be used as an alternative variation of learning for educators in the learning process to achieve the expected learning goals.
\end{abstract}

Keywords: Development, Learning, Games, Volleyball

Accepted: $09^{\text {th }}$ of January 2022

Correspondence author: Destriani, Universitas Sriwijaya. E-Mail: destriani@fkip.unsri.ac.id

DOI http://dx.doi.org/10.31851/hon.v5i1.5723 doi

(c) (i) (2)

Jurnal Halaman Olahraga Nusantara licensed under a Creative Commons Attribution-ShareAlike 4.0 International License 


\section{OLAARAGA}

\section{INTRODUCTION}

The civilization and progress of a country can be determined by several important factors, one of which is education. Updates in the field of education must always be carried out to improve the quality of education. Physical education which is part of education is an educational process that utilizes planned physical activities systematically aimed at developing and improving individual, organic, neuromuscular, perceptual, cognitive. The discovery learning method requires educators to organize activities in such a way that students can shape and test their abilities. It doesn't just let the students do what the students want (Zhou \& Brown, 2015). So as educators, there are many methods and strategies that can be used in the learning process.

Physical education is the optimal place to increase opportunities for physical activity during school. Various sources indicate that when high-quality physical education programs are implemented, students can learn the skills, confidence, and knowledge to be physically active during school, outside of school, and throughout life. Physical education, sports and health (PJOK) since 2020 has made a lot of progress that must be adjusted to the progress of the times and also related to the problem of the COVID-19 pandemic, it is hoped that existing learning can have a direct impact on students, where teachers carry out several stages of learning that are centered on students, including by planning, assisting, directing and facilitating students in learning (Mashud, 2015). The research that has been done (Destriana, Muslimin, \& Destriani, 2021) in this study carried out the development of the upper pass with a result of $87.5 \%$ using the development model there was an increase or improvement in the results of the upper pass of volleyball.

Previous research stated that through the development of volleyball game learning by changing some rules, net height, and field size can improve student learning outcomes (Destriani et al., 2019). (Juniardi \& Redno, 2019) this research was conducted to improve the skill of passing over in volleyball by using a 3 on 3 game. This study used a classroom action research design, a technique used to test 
HALAMAN Jendral A. Yani Street Lorong Gotong Royong 9/10 Ulu

the suitability of the test with the criteria of using a count class average learning success.

The development of varied learning techniques can help educators to design learning creatively so that the learning process becomes innovative, interesting, more qualified and can improve student learning outcomes. related to the structure of the game that leads to discovery and imagination for students. Teachers are given the opportunity to facilitate student learning experiences by using a student-centered approach (Leech, et al, 2016), so in accordance with the above opinion the development of learning techniques in this ball game provides opportunities for students to develop skills, knowledge, and attractiveness. towards learning. (Destriana, Destriani \& Herri Yusfi, 2018) research has been carried out by developing one basic technique, namely the basic service technique, so based on the previous research above, it is necessary to develop volleyball game learning techniques that can accommodate all the basic techniques in volleyball games, based on the following: above, so it is necessary to develop developments that can facilitate both the basic techniques and the rules of the game. The learning process that occurs is less able to motivate, interesting, fun, for students. This situation causes the competencies and indicators of achievement of lecture learning to be less than optimal, so it is necessary to develop learning techniques in volleyball games in the form of "3 on 3 games". This research is expected to produce a volleyball game learning development that can be used by educators to achieve learning objectives.

\section{METHOD}

The research method used in this study is the research and development ( $R$ \& D) method. The development research used is the Borg and Gall model. The steps used in the research are: 1) Conducting preliminary research and gathering information, including field observations and literature review. 2) Develop the initial product form 3) Evaluation of experts using one expert on physical education learning and volleyball game experts as well as small group trials using questionnaires and consultations and evaluations which are then analyzed, first 


\section{OLATRAGA

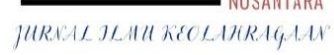 \\ Jendral A. Yani Street Lorong Gotong Royong 9/10 Ulu Palembang South Sumatera

product revision, product revision based on the results of the evaluation expert and small group trials. This revision is used for improvements to the initial product made by the researcher. 5) Field trials. 6) Revision of the final product to be carried out based on the results of field trials. 7) The final result of the development of volleyball game learning techniques produced through the revision of field trials.

The data analysis technique in this study uses a Likert scale. The data obtained is in the form of qualitative data which is used to determine the quality of the development of android-based learning media in volleyball games with the criteria; 1) Very Poor / Good / Appropriate, 2) Less Appropriate / Good / Appropriate, 3) Decent / Good / Appropriate, 4) Very Decent / Good / Appropriate, which can be seen in table 2 below:

Table 1. Likert scale

\begin{tabular}{ll}
\hline Scale & \multicolumn{1}{c}{ Description } \\
\hline 1 & Very Poor / Good / Appropriate \\
2 & Inappropriate/ Good/ Appropriate \\
3 & Appropriate/ Good/ Appropriate \\
4 & Very Decent/Good/ Appropriate \\
\hline
\end{tabular}

Percentage is intended to determine the status of something that is presented and presented remains in the form of a percentage. The formula for calculating the feasibility (Sugiyono, 2018) is as follows

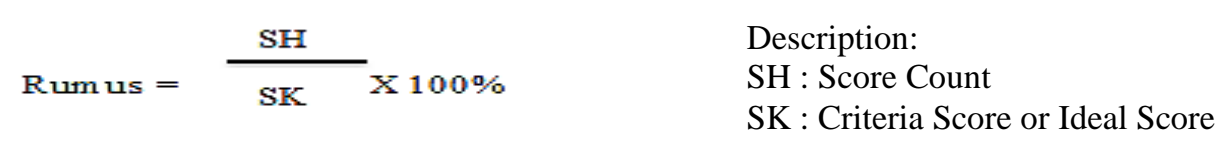

The result of the next data calculation is made in the form of a percentage multiplied by $100 \%$. After obtaining the percentage with this formula, the data from the development of the "games 3 on 3 " learning technique in this volleyball game are classified into four eligibility categories (Muhammad Ali \& Ansori, 2017) using the following scale: 
Table 2. Classification of Descriptive Analysis Percentage

\begin{tabular}{ccc}
\hline Percentage & Classification & Meaning \\
\hline $0-20 \%$ & Not good & Thrown away \\
$20,1-40 \%$ & Not good & Fixed \\
$40,1-70 \%$ & Pretty good & Used (conditional) \\
$70,1-90 \%$ & Good & Used \\
$90,1-100 \%$ & Very good & Used \\
\hline
\end{tabular}

\section{RESULT AND DISCUSSION}

\section{Result}

After conducting preliminary research and collecting information, including field observations and literature review where the researcher himself is a teacher at the research site, so that observation activities are carried out during the learning process. The next stage is to develop the initial product form based on the results of the previous research stages. After the initial product development, the initial product form was validated by physical education learning experts and volleyball game experts. Validation of the initial product form is based on three aspects, namely the cognitive, psychomotor, and affective domains. The results of the validation of experts in learning physical education and volleyball in the cognitive domain based on 12 statements obtained results for learning experts at number 1 , which is $67 \%$ which is included in the good enough category, and then the validation value at number 2 from the validation results of volleyball game experts is $70,8 \%$ with good category. So that it can be obtained an average result of $68.9 \%$ with a fairly good category, for more details can be seen in table 3 below:

Table 3. Expert Validation Assessment in the Cognitive Domain

\begin{tabular}{|c|c|c|c|c|c|c|c|c|c|c|c|c|c|c|c|c|c|}
\hline NO & $\begin{array}{l}\text { Expert } \\
\text { Code }\end{array}$ & & & & & & & atem & nent & & & & & $\Sigma$ & $\begin{array}{l}\text { Maximum } \\
\text { Value }\end{array}$ & $\begin{array}{c}\text { Percentage } \\
(\%)\end{array}$ & Category \\
\hline & & 1 & 2 & 3 & 4 & 5 & 6 & 7 & 8 & 9 & 10 & 11 & 12 & & & & \\
\hline 1 & WIB & 3 & 3 & 3 & 2 & 2 & 3 & 2 & 3 & 2 & 3 & 3 & 3 & 32 & 48 & 67 & Pretty good \\
\hline 2 & WL & 3 & 3 & 3 & 2 & 3 & 3 & 3 & 3 & 2 & 3 & 3 & 3 & 34 & 48 & 70,8 & Good \\
\hline
\end{tabular}




\section{HALAMAN OLAHRAGA

Next is the expert validation assessment based on the psychomotor domain, in this psychomotor domain for validation of physical education learning the results are $70 \%$ and for volleyball game validation results are $70 \%$, for more details it can be seen in table 4 below:

Table 4. Results of Expert Validation Assessment in the Psychomotor Realm

\begin{tabular}{cccccccccccccccc}
\hline NO & $\begin{array}{c}\text { Expert } \\
\text { Code }\end{array}$ & \multicolumn{1}{c}{ Statement } & & & $\Sigma$ & $\begin{array}{c}\text { Maximum } \\
\text { Value }\end{array}$ & $\begin{array}{c}\text { Percentage } \\
(\%)\end{array}$ & Category \\
\hline & & 1 & 2 & 3 & 4 & 5 & 6 & 7 & 8 & 9 & 10 & & & & \\
1 & WIB & 3 & 3 & 3 & 3 & 3 & 3 & 2 & 2 & 3 & 3 & 28 & 40 & 70 & Good \\
2 & WL & 3 & 3 & 3 & 3 & 3 & 3 & 3 & 2 & 2 & 3 & 28 & 40 & 70 & Good \\
& & \multicolumn{1}{c|c}{ Average } & & & & & 70 & Good \\
\hline
\end{tabular}

The results of the next assessment obtained in the cognitive domain with 6 submissions obtained results for learning experts with a percentage of $75 \%$ and volleyball game experts at $70.8 \%$, so that the average validation results in the affective domain are 72.9 which fall into the category good.

Table 5. Affective Area Expert Validation Results

\begin{tabular}{|c|c|c|c|c|c|c|c|c|c|c|}
\hline \multirow[t]{2}{*}{$\mathrm{NO}$} & $\begin{array}{l}\text { Expert } \\
\text { Code }\end{array}$ & \multicolumn{5}{|c|}{ Statement } & \multirow[t]{2}{*}{$\Sigma$} & \multirow{2}{*}{$\begin{array}{l}\text { Maximum } \\
\text { Value }\end{array}$} & \multirow{2}{*}{$\begin{array}{c}\text { Percentage } \\
(\%)\end{array}$} & \multirow[t]{2}{*}{ Category } \\
\hline & & 1 & 23 & 4 & 5 & 6 & & & & \\
\hline 1 & WIB & 3 & 33 & 3 & 3 & 3 & 18 & 24 & 75 & Good \\
\hline 2 & WL & 3 & 33 & 3 & 3 & 2 & 17 & 24 & 70,8 & Good \\
\hline & & & rage & & & & & & 72,9 & Good \\
\hline
\end{tabular}

Based on the results of the 3 domains in the cognitive, psychomotor, and affective domains with percentage values of $68.9 \%, 70 \%$ and $72.9 \%$ so that based on the percentage results and suggestions from experts, a revision was made to the initial product of the "games 3 on" learning technique. 3" in this volleyball game, after completing the revision, the research continued on a small-scale field trial.

"Games 3 on 3" this game was developed in a form of game that changes the playing area or field size to $16 \times 9$ meters, with each team's field length being 8 meters $x 9$ meters. The height of the net is changed to 2.2 meters, then the number of players in a team consists of 3 students in one team/team. Victory in one set ends with a score of 15 . Every student who has not had the opportunity to play on the field, the educator has distributed the duties of the other participants with duties as referees 1 and 2, then line judges, ball guards, and reserve players. 


\section{OLAHRAGA}

JURALILHUKCOLDRRAGHA
Jendral A. Yani Street Lorong Gotong Royong 9/10 U1 Palembang South Sumatera

email jurnal: jurnalhon@univpgri-palembang.ac.id situs web: http://www.univpgri-palembang.ac.id
Accredited SINTA 3

Furthermore, the results of this study are based on an assessment of 3 domains, the cognitive, psychomotor, and affective domains.

The results of research activities in the cognitive domain are the results of an assessment of knowledge about the rules of 3 on 3 games, how to rotate, playing areas, and determining victory in volleyball games based on the completion stage of suggestions and input from experts. This test is carried out by giving a questionnaire sheet containing 8 (eight) questions about the game "games 3 on 3". With a choice of answers "Yes" or "No". The results of the cognitive assessment can be seen in table 6 below:

Table 6. Student Cognitive Results Using “3 On 3” Games

\begin{tabular}{|c|c|c|c|c|}
\hline No & $\begin{array}{c}\text { Code } \\
\text { College } \\
\text { student }\end{array}$ & $\begin{array}{l}\text { Maximum } \\
\text { Value }\end{array}$ & $\begin{array}{c}\text { Answer } \\
\text { Right }\end{array}$ & $\begin{array}{c}\text { Percentage } \\
(\%)\end{array}$ \\
\hline 1 & PSD & 8 & 6 & 75 \\
\hline 2 & MAF & 8 & 7 & 87.5 \\
\hline 3 & $\mathrm{MF}$ & 8 & 7 & 87.5 \\
\hline 4 & SS & 8 & 7 & 87.5 \\
\hline 5 & FA & 8 & 6 & 75 \\
\hline 6 & MTR & 8 & 7 & 87.5 \\
\hline 7 & FR & 8 & 6 & 75 \\
\hline 8 & MAM & 8 & 7 & 87.5 \\
\hline 9 & FBP & 8 & 8 & 100 \\
\hline 10 & GYH & 8 & 7 & 87.5 \\
\hline 11 & MRA & 8 & 6 & 75 \\
\hline 12 & DRS & 8 & 7 & 87.5 \\
\hline 13 & MFJ & 8 & 6 & 75 \\
\hline 14 & AAT & 8 & 8 & 100 \\
\hline 15 & NLE & 8 & 7 & 87.5 \\
\hline 16 & GST & 8 & 7 & 87.5 \\
\hline 17 & AR & 8 & 6 & 75 \\
\hline 18 & MJP & 8 & 7 & 87.5 \\
\hline 19 & RAI & 8 & 7 & 87.5 \\
\hline 20 & SNK & 8 & 6 & 75 \\
\hline 21 & MK & 8 & 7 & 87.5 \\
\hline 22 & DK & 8 & 6 & 75 \\
\hline 23 & SFT & 8 & 7 & 87.5 \\
\hline 24 & FY & 8 & 7 & 87.5 \\
\hline 25 & RRP & 8 & 6 & 75 \\
\hline 26 & PKA & 8 & 6 & 75 \\
\hline 27 & EA & 8 & 7 & 87.5 \\
\hline 28 & PR & 8 & 5 & 62.5 \\
\hline Amount & & & & 2325 \\
\hline Average & & & & 83.03 \\
\hline
\end{tabular}




\section{HALAMAN Jendral A. Yani Street Lorong Gotong Royong 9/10 Ulu OLAHRAGA

Based on the table above, on the cognitive test of the students of the Physical Education Study Program in the Palembang class, the average percentage was $83.03 \%$. In general, the average obtained shows that in the cognitive domain, it is in the good category. Based on the analysis of items about the game area and the way of rotation, there are still many mistakes.

Assessment in the psychomotor domain is carried out through student performance which is assessed by researchers with predetermined assessment indicators. In this psychomotor domain, a performance test of the basic techniques of volleyball games is carried out, namely the top and bottom serve.

Table 7. Student Psychomotor Area Assessment Results

\begin{tabular}{|c|c|c|c|c|c|c|}
\hline \multirow[t]{2}{*}{ No } & \multirow{2}{*}{$\begin{array}{c}\text { Code } \\
\text { College } \\
\text { student }\end{array}$} & \multicolumn{2}{|c|}{ Basic technique } & \multirow[t]{2}{*}{$\Sigma$} & \multirow[t]{2}{*}{$\begin{array}{l}\text { Maximum } \\
\text { Value }\end{array}$} & \multirow[t]{2}{*}{$\begin{array}{c}\text { Percentage } \\
(\%)\end{array}$} \\
\hline & & Under Pass & Service & & & \\
\hline 1 & PSD & 3 & 3 & 6 & 8 & 75 \\
\hline 2 & MAF & 2 & 3 & 5 & 8 & 62.5 \\
\hline 3 & MF & 2 & 4 & 6 & 8 & 75 \\
\hline 4 & SS & 3 & 3 & 6 & 8 & 75 \\
\hline 5 & FA & 2 & 3 & 5 & 8 & 62.5 \\
\hline 6 & MTR & 3 & 4 & 7 & 8 & 87.5 \\
\hline 7 & FR & 3 & 3 & 6 & 8 & 75 \\
\hline 8 & MAM & 3 & 3 & 6 & 8 & 75 \\
\hline 9 & FBP & 2 & 3 & 5 & 8 & 62.5 \\
\hline 10 & GYH & 3 & 4 & 7 & 8 & 87.5 \\
\hline 11 & MRA & 3 & 3 & 6 & 8 & 75 \\
\hline 12 & DRS & 3 & 3 & 6 & 8 & 75 \\
\hline 13 & MFJ & 4 & 4 & 8 & 8 & 100 \\
\hline 14 & AAT & 3 & 3 & 6 & 8 & 75 \\
\hline 15 & NLE & 3 & 4 & 7 & 8 & 87.5 \\
\hline 16 & GST & 3 & 3 & 6 & 8 & 75 \\
\hline 17 & AR & 2 & 3 & 5 & 8 & 62.5 \\
\hline 18 & MJP & 4 & 4 & 8 & 8 & 100 \\
\hline 19 & RAI & 3 & 4 & 7 & 8 & 87.5 \\
\hline 20 & SNK & 4 & 4 & 8 & 8 & 100 \\
\hline 21 & MK & 4 & 4 & 8 & 8 & 100 \\
\hline 22 & DK & 3 & 3 & 6 & 8 & 75 \\
\hline 23 & SFT & 2 & 3 & 5 & 8 & 62.5 \\
\hline 24 & FY & 4 & 3 & 7 & 8 & 87.5 \\
\hline 25 & RRP & 3 & 4 & 7 & 8 & 87.5 \\
\hline 26 & PKAN & 4 & 4 & 8 & 8 & 100 \\
\hline 27 & EA & 3 & 4 & 7 & 8 & 87.5 \\
\hline \multirow[t]{3}{*}{28} & PR & 4 & 4 & 8 & 8 & 100 \\
\hline & Amount & & & & & 2275 \\
\hline & Average & & & & & 81.25 \\
\hline
\end{tabular}


The results of the service, most of the students have been able to serve up with the correct technique and can enter the opponent's area, and there are only a few participants who are wrong in technique and have not been able to serve into the opponent's area, but in general the results of serving on students are good. Learning outcomes are assessed through the affective domain using an observation sheet consisting of several assessment indicators, namely the value of cooperation, honesty, and responsibility.

The assessment on the indicators of cooperation with values appears such as helping friends who ask for help, playing is not individual, willing to teach friends who can't, and clear division of group tasks. Then on the honest aspect with the attitude that appears, namely saying what it is, playing the game according to the procedure, admitting mistakes made, and expressing opinions according to the truth. And the aspect of responsibility with the attitude that should appear is being disciplined, obeying the rules, being willing to be punished if wrong, and carrying out the division of tasks from the group agreement. Based on the assessment indicators above, data on the results of the affective domain is obtained, for more details, it can be seen in table 8 below:

Table 8. Student Affective Area Assessment Results

\begin{tabular}{|c|c|c|c|c|c|c|c|}
\hline \multirow[t]{2}{*}{ No } & \multirow{2}{*}{$\begin{array}{c}\text { Code } \\
\text { College } \\
\text { student }\end{array}$} & \multicolumn{3}{|c|}{ Affective Assessment } & \multirow[t]{2}{*}{$\Sigma$} & \multirow{2}{*}{$\begin{array}{l}\text { Maximum } \\
\text { Value }\end{array}$} & \multirow{2}{*}{$\begin{array}{c}\text { Percentage } \\
(\%)\end{array}$} \\
\hline & & Cooperation & Honest & $\begin{array}{c}\text { Responsibili } \\
\text { ty }\end{array}$ & & & \\
\hline 1 & PSD & 3 & 3 & 4 & 10 & 12 & 83.3 \\
\hline 2 & MAF & 2 & 3 & 3 & 8 & 12 & 66.6 \\
\hline 3 & $\mathrm{MF}$ & 3 & 3 & 4 & 10 & 12 & 83.3 \\
\hline 4 & SS & 3 & 3 & 2 & 8 & 12 & 66.6 \\
\hline 5 & FA & 3 & 3 & 4 & 10 & 12 & 83.3 \\
\hline 6 & MTR & 2 & 3 & 3 & 8 & 12 & 66.6 \\
\hline 7 & FR & 3 & 4 & 4 & 11 & 12 & 91.6 \\
\hline 8 & MAM & 4 & 4 & 3 & 11 & 12 & 91.6 \\
\hline 9 & FBP & 3 & 3 & 3 & 9 & 12 & 75 \\
\hline 10 & GYH & 3 & 3 & 3 & 9 & 12 & 75 \\
\hline 11 & MRA & 3 & 3 & 3 & 9 & 12 & 75 \\
\hline 12 & DRS & 3 & 3 & 4 & 10 & 12 & 83.3 \\
\hline 13 & MFJ & 3 & 3 & 3 & 9 & 12 & 75 \\
\hline 14 & AAT & 4 & 3 & 4 & 11 & 12 & 91.6 \\
\hline 15 & NLE & 3 & 3 & 3 & 9 & 12 & 75 \\
\hline 16 & GST & 3 & 2 & 3 & 8 & 12 & 66.6 \\
\hline
\end{tabular}




\section{OLAHRAGA



Jendral A. Yani Street Lorong Gotong Royong 9/10 Ulu

Palembang South Sumatera

\begin{tabular}{llllllll}
\hline 17 & AR & 3 & 2 & 3 & 8 & 12 & 66.6 \\
18 & MJP & 4 & 3 & 3 & 10 & 12 & 83.3 \\
19 & RAI & 3 & 3 & 4 & 10 & 12 & 83.3 \\
20 & SNK & 3 & 3 & 4 & 10 & 12 & 83.3 \\
21 & MK & 4 & 3 & 3 & 10 & 12 & 83.3 \\
22 & DK & 4 & 3 & 4 & 11 & 12 & 91.6 \\
23 & SFT & 3 & 3 & 4 & 10 & 12 & 83.3 \\
24 & FY & 2 & 3 & 3 & 8 & 12 & 66.6 \\
25 & RRP & 2 & 3 & 3 & 8 & 12 & 66.6 \\
26 & PKA & 3 & 2 & 3 & 8 & 12 & 66.6 \\
27 & EA & 3 & 2 & 3 & 8 & 12 & 66.6 \\
28 & PR & 3 & 3 & 2 & & 66.6 \\
& Amount & & & & & 2158.3 \\
\end{tabular}

Based on table 8 the assessment on the affective domain of the Physical

Education study program students with a total of 28 people through observation using process assessment obtained an average percentage of $77.08 \%$ and this result is classified as good. Based on the table above, it can be seen that the attitude of cooperation, honesty, and responsibility in general when the volleyball game process takes place can be seen an attitude of cooperation, honesty, and responsibility by being given several tasks according to the form of the game given, although from the 4 assessments not all attitudes can be seen. appears or is fulfilled. This shows that at this stage of research the development of learning techniques "games 3 on 3 " in the affective domain can already be used for the learning process.

The data from the assessment of 3 domains, namely the cognitive, psychomotor, and affective domains, amounted to $83.03 \%, 82.25 \%$, and $77.08 \%$, so based on these data it can be seen that the overall learning outcomes of the three domains using "games 3 on 3" have good. For student learning outcomes already in the good category.

\section{Discussion}

The results of this research and development can be a form of learning technique that can be used by educators in the teaching and learning process. In this study, learning outcomes are assessed in 3 domains, namely cognitive, psychomotor and affective. Students get scores based on assessment indicators that have been made according to the implementation of each basic technique. In 
the psychomotor aspect, the maximum value for each basic technique is the value "4" with the provisions that have been made. The research conducted by Pujianto et al., that this study resulted in a game-based pass training model in football, the results of this study explain that using game-based training methods can improve football skills (Pujianto et al., 2020). So that playing techniques can also be used as material for teaching volleyball material. The results in the psychomotor domain with process assessment, namely the basic techniques of upper and lower service, obtained an average percentage of $81.25 \%$ and this result is in the good category. This shows that it can be used and will be revised according to the shortcomings in the learning process (Broek et al., 2011). Data collection techniques using volleyball playing skills tests are service tests, passing tests and smash tests. The test was conducted to determine the volleyball game skills that had been treated with self-check style training (Daryono, D., \& Almy, M. A, 2021).

Furthermore, in the research conducted (Rezeki W, Dwi C, and Setiyo H. 2018) this study was used to determine the increase in learning motivation and learning outcomes for the lower end in volleyball games through the application of the Student Teams Achievement Division (STAD) cooperative learning method, based on data the results of the research above that there are good bottom-line learning outcomes using "games 3 on 3 " based on this, the improvement in bottom-line results can be increased through several learning methods using games and various other learning methods.

Furthermore, the results of the bottom pass test, students are able to do the basic techniques correctly, but in general, for the bottom pass, students are not able to direct the ball according to the target or the direction of the pass that matches the arrival of the ball. (Ajayati, 2017) the development of a low-level volleyball learning model for junior high school age with results to see the effectiveness, efficiency, and attractiveness of the model made using the Research \& Development (R \& D) method from Borg and Gall that the lowest result in This research is increasing, based on this research, it can be seen that to improve the 


\section{OLAARRAA}

results of the bottom row, it is necessary to form and play games that are in accordance with the needs of students.

Physical education teachers have instilled positive characters in students and always play an active role when learning and outside of class hours, physical education teachers have not been able to fully incorporate character education values into learning conceptualized in the Learning Implementation Plan but physical education teachers have instilled some positive character (Mutia et al., 2019), in accordance with the results of the research above that an educator must pay attention to character values, so that the development of "3 on 3 games" can provide the application of these character values through the value of cooperation, honesty, and the value of responsibility.

In accordance with the research on the provision of video learning methods, it was explained that the results of the study showed that the experimental group participants were better in task orientation than the control group after the experimental activity, the results of this study explained that the bottom pass of the participants was better than the control group. The existence of evaluation or error correction activities or feedback is beneficial for physical education teachers and trainers because it helps students/athletes not only to learn skills but also to keep them motivated in their sport (Barzouka et al., 2015).

In accordance with the opinion of Hall, R.A (2011) that the affective domain is a domain that is often neglected in the learning process, so an educator must provide a complete learning process for students. In a cooperative relationship with learning activities, the most important thing is how to create a learning process that directs students to carry out learning activities and how educators also make efforts to be able to foster student collaboration so that they can carry out good learning activities. In research conducted (Kurniawan, AE, 2012), it is explained that by using the Borg and Gall development stage the results at the expert validation stage, namely physical education experts and learning experts on learning products or models that have been tested into smallscale tests, can immediate product revision. The product revision process is based 
on the advice of Physical Education experts and learning experts on the obstacles and problems that arise after small-scale trials, namely with a percentage value of $89.59 \%$ with a layered mini volleyball learning model product that has met good criteria so that it can be used for students. In line with this research, at this smallscale trial stage, the results were obtained in a good category, so that it can be used for the learning process.

\section{CONCLUSION}

Based on the results of the data and discussion above, it can be concluded that the development of "3 on 3 games", on the learning outcomes of volleyball games for students of Physical Education, Faculty of Medicine, Sriwijaya University, is in the good category and is suitable for learning volleyball games. The results of small-scale trials were assessed through the cognitive, psychomotor, and affective domains. "Games 3 on 3" in volleyball games can be used for learning volleyball games and can be used as an alternative variation of learning for educators in the learning process to achieve the expected learning goals.

\section{ACKNOWLEDGEMENT}

Thanks to the Rector and the Sriwijaya University Research and Community Service Institute who have funded this research, support from the Leaders of the Teacher Training and Education Faculty for the facilities used, and thanks to students and all lecturers who have collaborated during the research, this research was funded under the Scheme Sriwijaya University Science and Technology.

\section{REFERENCE}

Ajayati, T. (2017). The Learning Model of Forearm Passing In Volleyball for Junior High School. JETL (Journal Of Education, Teaching and Learning). https://doi.org/10.26737/jetl.v2i2.289.

Barzouka, K., Sotiropoulos, K., \& Kioumourtzoglou, E. (2015). The effect of feedback through an expert model observation on performance and 
learning the pass skill in volleyball and motivation. Journal of Physical

Education and Sport. https://doi.org/10.7752/jpes.2015.03061.

Broek, G. Vande, Boen, F., Claessens, M., Feys, J., \& Ceux, T. (2011). Comparison of three instructional approaches to enhance tactical knowledge in volleyball among university students. Journal of Teaching in Physical Education. https://doi.org/10.1123/jtpe.30.4.375.

Daryono, D., \& Almy, M. A. (2021). Peningkatan Keterampilan Bermain Bola Voli Mahasiswa Melalui Latihan Gaya Self Check. Halaman Olahraga Nusantara (Jurnal Ilmu Keolahragaan), 4(1), 89-99.

Destriana, D., Muslimin, M., \& Destriani, D. (2021). The Development of Overhead Pass Learning Models in Volleyball. Halaman Olahraga Nusantara (Jurnal Keolahragaan). https://doi.org/10.31851/hon.v4i2.5300.

Destriani, D., Destriana, D., Switri, E., \& Yusfi, H. (2019). The development of volleyball games learning for students. Jurnal SPORTIF: Jurnal Penelitian Pembelajaran. https://doi.org/10.29407/js_unpgri.v5i1.12605.

Gert V B, Filip B, Manu C, Jos F, and Tanja C. 2011. Comparison of Three Instructional Approach to Enhance Tactical Knowledge in Volleyball among University students. Journal of Teaching in Physical Education. 30. 377-378.

Giatsis , G. 2003. The effect of changing the rules on score fluctuation and match duration in the FIVB women's beach volleyball. International Journal of Performance Analysis in Sport, 3, 57-64.

Hall, R. A. (2011). Affective Assessment: The Missing Piece of the Educational Reform Puzzlell. Academic journal article from Delta Kappa Gamma Bulletin. Vol. 77, No.2.

Juniardi, A., \& Redno, R. (2019). Upaya Meningkatkan Keterampilan Passing Atas Bola Voli Dengan Menggunakan Permainan 3 On 3 Pada Kelas Vii Di Smp Negeri 21 Kota Bengkulu. Multilateral Jurnal Pendidikan Jasmani Dan Olahraga. https://doi.org/10.20527/multilateral.v18i1.6567.

Lin, C.-S \& Wu, R.-W. (2016). Effects of Web-Based Creative Thinking Teaching on Students' Creativity and Learning Outcome. EURASIA Journal of Mathematics, Science \& Technology Education. 12. 1675-1684. 10.12973/eurasia.2016.1558a.

Mashud. (2015). Pendekatan Pembelajaran Pendidikan Jasmani Olahraga dan Kesehatan di Era Abad 21. Jurnal Multilateral.

Mohamad Ali \& Ansori. (2017). Psikologi Remaja : Perkembangan Peserta Didik. Jakarta Bumi Aksara 


\section{OLATRAGA}

JUREAL HLIIIKCOLIRAGIAT
Jendral A. Yani Street Lorong Gotong Royong 9/10 Ulu Palembang South Sumatera

email jurnal: jurnalhon@univpgri-palembang.ac.id situs web: http://www.univpgri-palembang.ac.id
Accredited

SINTA 3

Mutia, M., Warni, H., \& Sarmidi, S. (2019). Peran Guru Pendidikan Jasmani Dalam Menanamkan Karakter Keapada Peserta Didik Di Sd Negeri AtuAtu Kecamatan Pelaihari Kabupaten Tanah LAUT. Multilateral Jurnal Pendidikan Jasmani Dan Olahraga. https://doi.org/10.20527/multilateral.v18i2.7623

Pujianto, D., Sutisyana, A., \& Arwin, A. (2020). Pengembangan Model Latihan Sasaran Berbasis Permainan Untuk Meningkatkan Kemampuan Passing Sepakbola. Multilateral Jurnal Pendidikan Jasmani Dan Olahraga. https://doi.org/10.20527/multilateral.v19i1.8333

Rezeki W, Dwi C, and Setiyo H. 2018. Improve the Motivation of Learning and Learning Outcomes Passing Down Volleyball Through Cooperative Learning Model. Journal Physical Education, Health, and Sport. 5(2). 41

Sugiyono. (2018). Metode Penelitian Kuantitatif, Kualitatif dan R\&D. Bandung: Alfabeta.CV [26] Mohamad Ali \& Ansori. (2017). Psikologi Remaja : Perkembangan Peserta Didik. Jakarta Bumi Aksar

Zhou, M., \& Brown, D. (2015). Educational Learning Theories: 2nd Edition. In Education Open Textbooks. 